The mean F.D.P. concentration of the women taking oral contraceptives, $15 \cdot 78 \pm 9.92 \mu \mathrm{g} / \mathrm{ml}$, was higher than that of any other group, but this figure was influenced by two values of 37.6 and $45.1 \mu \mathrm{g} / \mathrm{ml}$, which were much higher than in any other women in the survey. There is no statistically significant difference between any of the groups shown in Table II; and the correlation coefficient $(r=0.02)$ between menstrual blood loss and serum F.D.P. is also not significant.

\section{Discussion}

Using the tanned red cell haemagglutination inhibition immunoassay, Basu (1970) showed a significant rise in serum F.D.P. in all stages of the menstrual cycle in women complaining of menorrhagia, compared with a control group. Moreover, in both normal and abnormal groups there was a peak in serum F.D.P. concentration coinciding with menstruation. Basu (1970) concluded that these systemic manifestations of increased invivo fibrinolysis were evidence of intensive local intrauterine activity. However, Das et al. (1967) were unable to find any cyclical fluctuation in systemic F.D.P. concentration in four normal women and, in particular, there was no peak during menstruation. Moreover, though many of the women in the present study had menstrual losses as large as those experienced by women who complain of menorrhagia (Hytten et al., 1964) we were unable to show a positive correlation between menstrual loss and circulating F.D.P. concentration.

Why our findings differ from Basu's (1970) is difficult to explain. His patients may have differed in some relevant way from our subjects, since women who seek medical help may do so primarily because of a recent change in the volume of blood lost at menstruation, and such a change might be associated with temporarily increased local intrauterine fibrinolysis and so be reflected in raised systemic levels of serum F.D.P. However, this explanation is unlikely as Rybo (1966) showed that increased intrauterine fibrinolysis, as measured by high levels of endometrial plasminogen activator, is associated with the actual volume of menstrual blood lost rather than with the complaint of menorrhagia.

Minor, but important, differences in the F.D.P. assay technique between Basu's (1970) laboratory and our own may also be relevant; in particular, the specificity of the antisera used, with special reference to the relative sensitivity of tests to detect the antigenically dissimilar D and E fragments. Checking our own antiserum with purified $D$ and $E$ products has shown extreme sensitivity to fragment $D$ and only slightly less sensitivity to $E$.

Consideration of previous studies in which serum F.D.P. estimations have often failed to show evidence of intense localized fibrin deposition and fibrinolysis, as in the case of renal homotransplantation (Colman et al., 1969; Clarkson et al., 1970) and of proliferative glomerulonephritis (Clarkson et al., 1971), makes the absence of a significant rise in serum F.D.P. in women with heavy menstrual blood loss, as reported in this paper, not unexpected. Thus, from a practical point of view, at the present time we have no reason to believe that isolated or serial measurements of serum F.D.P. in women complaining of menorrhagia will assist the gynaecologist in selecting those patients who might benefit from oral antifibrinolytic agents (Nilsson and Rybo, 1971).

We wish to thank Dr. A. J. G. Newton and his partners and the patients in Broomhill, Northumberland, for their co-operation. We are also grateful for criticism and advice during the preparation of this paper from Dr. J. D. Cash, Deputy Director, S.E. Scotland Regional Blood Transfusion Centre. Mr. J. Barclay helped with the F.D.P. assays.

\section{References}

Basu, H. K. (1970). British Medical fournal, $1,74$.

Cheyne, G. A., and Shepherd, M. M. (1970). fournal of Medical Laboratory Technology, 27, 350.

Clarkson, A. R., Morton, J. B., and Cash, J. D. (1970). Lancet, 2, 1220.

Clarkson, A. R., MacDonald, M. K., Petrie, J. J. B., Cash, J. D., and Robson, J. S. (1971). British Medical fournal, 3, 447.

Cole, S. K., Billewicz, W. Z., and Thomson, A. M. (1971). Fournal of Obstetrics and Gynaecology of the British Commonwealth, 78, 933.

Colman, R. W. Braun, W. E., Busch, G. J., Dammin, G. J., and Merrill, J. P. (1969). New England fournal of Medicine, 281, 685.

Das, $\dot{P}$. C. (1970). Fournal of Clinical Pathology, 23, 149.

Das, P. C., Allan, A. G. E., Woodfield, D. G., and Cash, J. D. (1967). British Medical Fournal, 4, 718.

Hoq, M., and Das, P. C. (1971). Scandinavian fournal of Haematology, Suppl. No. 13, p. 101.

Hytten, F. E., Cheyne, G. A., and Klopper, A. I. (1964). Fournal of Obstetrics and Gynaecology of the British Commonwealth, 71, 255.

Merskey, C., Kleiner, G. J., and Johnson, A. J. (1966). Blood, 28, 1.

Nilsson, I. M., and Bjorkman, S. E. (1965). Acta Medica Scandinavica,

177,445 .
Nilsson, L., and Rybo, G. (1971). American fournal of Obstetrics and Gynecology, 110, 713 .

Rybo, G. (1966). Acta Obstetricia et Gynecologica Scandinavica, 45, 429.

\title{
Bread Iodine Content and Thyroid Radioiodine Uptake: a Tale of Two Cities
}

\author{
BERNARD A. SACHS, EDWARD SIEGEL， BENJAMIN N. HORWITT, ELSIE SIEGEL
}

British Medical fournal, 1972, 1, 79-81

\section{Summary}

The iodine content of bread consumed in the Bronx, New York, was found to be significantly lower than that of bread consumed in Columbia, Missouri. This difference in dietary

Albert Einstein College of Medicine, Bronx, New York

BERNARD A. SACHS, M.D., Associate Clinical Professor of Medicine; and Senior Endocrinologist, Montefiore Hospital and Medical Center, Bronx, New York

University of Missouri School of Medicine, Columbia, Missouri EDWARD SIEGEL, PH.D., Professor of Radiological Sciences and

ELSIE SIEGEL, M.s., Research Associate, Department of Radiology

Bio-Science Laboratories, Van Nuys, California

BENJAMIN N. HORWITT, PH.D., Director, Department of Endocrinology intake of iodine could account for the lowered range of normal values for 24-hour ${ }^{131}$ I uptake tests in Columbia, and the persistence of the same normal range for this test over the past 28 years in the Bronx. A population with high iodine intake requires higher doses of radioactive iodine in the diagnosis and treatment of thyroid disease. Questions are raised regarding the relationship of high iodine intake to the risk of developing thyrotoxicosis.

\section{Introduction}

The 24-hour thyroidal uptake of radioiodine is accepted as a reliable index of thyroid function. Well-known factors that influence the uptake are iodine-containing medications or diagnostic procedures using iodine-containing contrast media. In the absence of these the uptake of radioiodine by the 
thyroid seems to be reciprocally related to the daily ingestion of iodide (Stanbury, 1969).

Decreases in normal values for thyroidal radioiodine uptake due to diets high in iodine have been reported in the U.S.A. (Pitman et al., 1969; Caplan and Kujak, 1971). The major source of dietary iodine in recent years appears to be commercially manufactured white bread (London et al., 1965). During the past decade more than half the commercial bakeries have been found to use additives containing large amounts of iodine and iodate. Despite these reports, however, no change in the normal values for 24-hour radioiodine uptake $(15-40 \%)$ has occurred during the 28 years this test has been performed at Montefiore Hospital in the Bronx, New York. On the other hand, a pronounced decrease in the normal range of thyroid iodine uptake $(5-15 \%)$ has been noted by one of us (E.S.) in Columbia, Missouri. It was decided to compare the iodine content of commonly eaten breads in the Bronx and in Columbia to determine whether local dietary habits could account for these differences.

\section{Methods and Materials}

Twenty-three different kinds of bread and rolls baked by independent (neighbourhood) and commercial bakeries were purchased in the Bronx and in Columbia. In the Bronx these were baked by three independent and seven commercial bakeries. In Columbia they came from three independent sources and eight commercial bakeries. Samples also were obtained from an independent bakery in St. Louis which is located 125 miles $(200 \mathrm{~km})$ east of Columbia.

The wet and dry weights per slice or per roll were determined and the total iodine in the bread was determined by a modification of the Barker dry ash procedure for protein-bound iodine (Barker et al., 1951). Approximately $50 \mathrm{mg}$ of a dried, ground sample of bread was weighed accurately and transferred to a test tube. To each tube $0.5 \mathrm{ml}$ of $2 \mathrm{~N} \mathrm{Na}_{2} \mathrm{CO}_{3}$ in $1 \% \mathrm{KClO}_{3}$ was added. These were then dried at 100 to $105^{\circ} \mathrm{C}$. The material was then incinerated for 30 minutes at $625^{\circ} \mathrm{C}$. The ceric arsenite reaction was carried out on the ash as for the protein-bound iodine determination. The results were translated into microgrammes of iodine per weight of sample and per portion (slice or roll).

\section{Results}

The iodine content of the breads in the Bronx ranged from undetectable to $9.5 \mu \mathrm{g}$ per slice and in Columbia from undetectable to $268 \mu \mathrm{g}$ per slice (Fig. 1). None of the Bronx breads and five of the Columbia breads had greater than $50 \mu \mathrm{g}$ of iodine per slice or per roll. Four of the Bronx breads contained greater than $0.2 \mu \mathrm{g}$ of iodine per gramme. Three of the four contained egg as a prime ingredient (chalah, egg roll, enriched commercial bread). The fourth was whole-wheat bread from a national grocery chain. Whole-wheat bread from this same chain in Missouri contained a similar amount of iodine. Ten of the Missouri breads contained greater than $0.2 \mu \mathrm{g}$ of iodine per gramme (Fig. 2). Five of them were white and three wheat, all produced by commercial bakeries.

\section{Discussion}

It would seem that the difference in normal ranges for 24-hour radioiodine thyroidal uptakes between Bronx, New York, and Columbia, Missouri, could be explained by the relatively low iodine content of the breads commonly eaten in the Bronx and the high iodine content of the breads usually eaten in Columbia. The local population in the Bronx habitually purchases unpackaged bread baked on the premises by Jewish bakers. To a lesser extent packaged commercial bread is used,

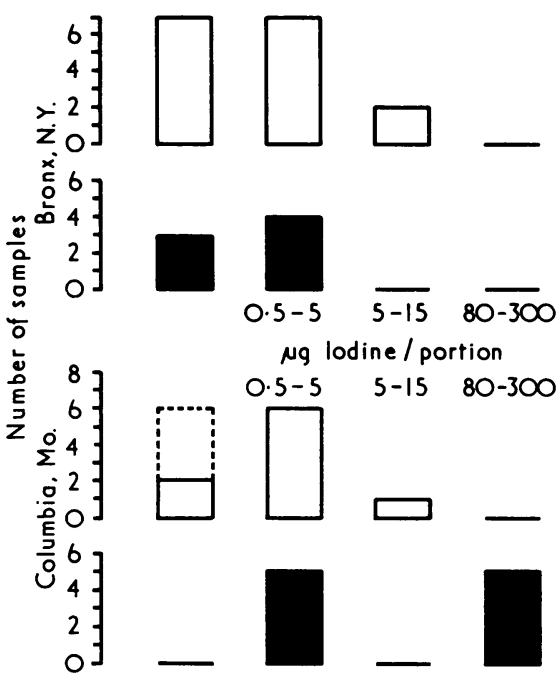

FIG. 1-Microgrammes of iodine per portion (roll or slice of bread) in bread samples from the Bronx, New York, and Columbia, Missouri. The white columns indicate samples from independent (neighbourhood) bakeries and the black columns from commercial bakeries. The column enclosed by interrupted lines represents four samples from $\mathrm{St}$. Louis, Missouri. The samples represented by the columns on the left contained less than 0.05 $\mu \mathrm{g} / \mathrm{g}$.

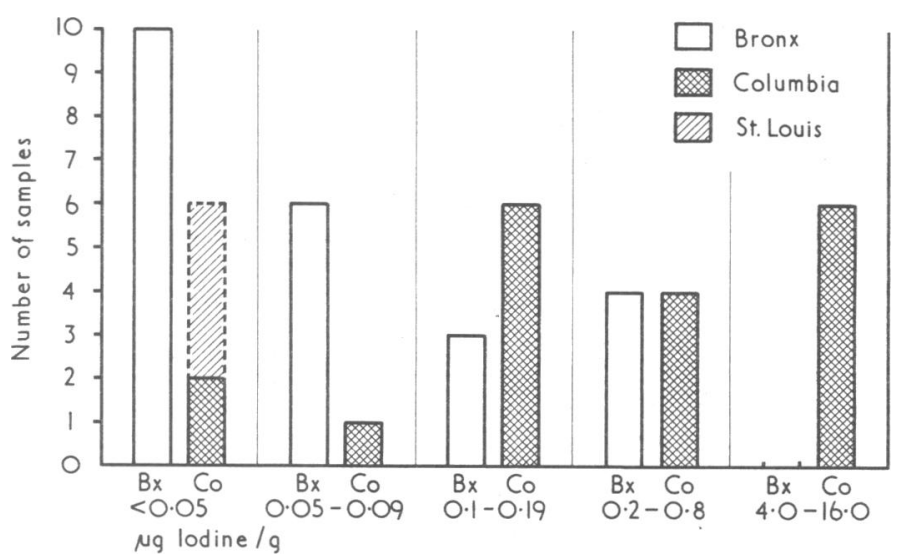

FIG. 2-Microgrammes of iodine per gramme in bread samples from all sources.

but even this seemed to have a lower iodine content than the breads available in Columbia. In the latter area the breads have the highest iodine content, though there was some overlap.

Of great interest is the fact that breads obtained from an independent Jewish bakery in St. Louis, 125 miles $(200 \mathrm{~km})$ east of Columbia, were low in iodine, similar to those breads in the Bronx. However, the local population in Columbia uses much more packaged commercial bread than independent local bakery bread.

Ingestion of bread rich in iodine is of potential clinical importance, especially in the presence of recent data indicating that an increase in dietary iodine may be a widespread phenomenon in the U.S.A. (Oddie et al., 1970). An iodine intake of as little as $300 \mu \mathrm{g}$ daily has been shown to partially suppress 24-hour thyroidal iodine uptake tests. Severe suppression of uptake is achieved with $1,000 \mu \mathrm{g}$ daily (Saxena et al., 1963). Regular dietary iodine plus four slices of iodinerich bread daily would readily achieve suppressive levels of iodine intake.

The low thyroidal radioiodine uptake in Columbia could be explained by simple dilution of the radioiodine by excess dietary ${ }^{127}$ I from bread. It has been shown that subjects who ingest liberal quantities of iodide, with resulting high plasma inorganic iodide concentrations, maintain normal hormone secretion by depressing thyroidal iodine clearance (Pittman 
et al., 1969) and by leakage of iodide-like material from the gland (DeGroot, 1966).

One must consider the significance of long-standing diets high in iodide. In Tasmania the addition of iodate in the bread-making process was followed closely by a pronounced increase in the incidence of thyrotoxicosis (Vidor et al., 1968). Thyrotoxicosis has been induced by supplementing the diet with as little as $1.5 \mathrm{mg}$ of iodide daily over the course of a few weeks, and after treatment with iodized oil injection. This phenomenon has been reported only in areas of endemic goitre. The possibility of an increased incidence of thyrotoxicosis due to high iodide intake in areas without endemic goitre is present, though this possibility was considered unlikely (Stanbury, 1969).

Immediate disadvantages of high iodide intake are principally concerned with the administration of radioiodine for scanning and uptake studies. The lower thyroidal uptakes make it necessary to administer higher doses of ${ }^{131} I$ for scanning and uptake studies to maintain quality, which results in more radiation delivered to the thyroid and whole body. In addition, larger therapeutic doses of radioiodine for thyrotoxicosis and thyroidal ablation also are necessary. A less commonly encountered disadvantage of high iodide intake occurs in patients with functioning metastases from thyroid cancer. It is likely that high dietary intake of iodide would result in diminished ${ }^{131}$ I uptake by functioning metastases, thereby limiting the efficacy of radioiodine therapy in this disorder.
It would seem useful to have a "local factor" for each community which could be used in comparing radioiodine uptakes from one area to another. For example, if the Bronx range was regarded as 1 , the Columbia factor would be $0 \cdot 4$. In this manner reported results could be readily adjusted for comparison.

Send reprint requests to: Dr. Bernard A. Sachs, Montefiore Hospital and Medical Center, 111 East 210th Street, Bronx, New York 10467, U.S.A.

\section{References}

Barker, S. B., Humphrey, M. J., and Soley, M. H. (1951). fournal of Clinical Investigation, 30, 55

Caplan, R. H., and Kujak, R. (1971). Fournal of the American Medical Association, 215, 916 .

DeGroot, L. J. (1966). Fournal of Clinical Endocrinology and Metabolism, 26, 149.

London, W. T., Vought, R. L., and Brown, F. A. (1965). New England Fournal of Medicine, 273, 381 .

Oddie, T. H., Fisher, D. A., McConahey, W. M., and Thompson, C. S. (1970). Fournal of Clinical Endocrinology and Metabolism, 30, 659 .

Pittman, J. A., Dailey, G. E., and Beschi, R. J. (1969). New England fournal of Medicine, 280, 1431.

Saxena, K. M., Chapman, E. M., and Pryles, C. V. (1963). Science, 138, 430.

Stanbury, J. B. (1969). New England fournal of Medicine, 280, 1474

Vidor, G., et al. (1968). Australasian Annals of Medicine, 17, 162.

\title{
Kidney Function after Methoxyflurane Analgesia during Labour
}

\author{
MICHAEL ROSEN, P. LATTO, A. W. ASSCHER
}

\section{Introduction}

Several reports of nephrotoxicity following prolonged methoxyflurane anaesthesia have been published (Crandall et al., 1966; Frascino et al., 1970; Mazze et al., 1971). Present views tend to favour a dose-dependent toxicity (Vandam, 1970; Mazze et al., 1971; Committee on Anesthesia, 1971). In Great Britain methoxyflurane has, after extensive trials, been approved by the Central Midwives Board for use as a self-administered inhalation analgesic during labour (Major et al., 1966; Jones et al., 1969; Rosen et al., 1969). In some 3,000 obstetric patients who had received methoxyflurane, anaesthesia renal complications were not observed (Lapointe and Bele-Binda, 1970). Nevertheless, even with the lower concentration used for analgesia some doubt might exist whether tubular dysfunction occurs in these circumstances. The present studies were designed to investigate this.

had nitrous oxide analgesia, the urinary and blood urea concentrations were measured on the morning of discharge from hospital. There were no significant differences between the groups. These results suggest that methoxyflurane is not nephrotoxic when used as a selfadministered analgesic.

University Hospital of Wales, Royal Infirmary, Cardiff CF2 1SZ

MICHAEL ROSEN, F.F.A. R.C.S., Consultant Anaethetist

P. LATTO, F.F.A. R.C.S., D.A., Senior Registrar in Anaesthetics

Medical Unit, Welsh National School of Medicine, K.R.U.F. Institute of Renal Disease, Royal Infirmary, Cardiff

A. W. ASSCHER, M.D., F.R.C.P., Reader in Medicine
One study was undertaken to examine tubular function in some detail before and for some days after methoxyflurane inhalation, and another to screen a larger group of mothers. Since renal function tests after delivery may be difficult to interpret the mothers who had methoxyflurane were compared with others who had nitrous oxide, which has not been implicated as a nephrotoxic agent.

The first study, in one obstetric unit, included 50 mothers delivery. These patients were randomized with regard to the

\section{Method} judged by the midwife as requiring inhalation analgesia for 